greats, contain a considerable number of all arts students, the joint schools involving science subjects, philosophy, psychology and physiology, and economics and engineering, have been small and hard to get into. This will also be true of the two new schools. In them, as in PPP, the component subjects will be taught separately under the supervision of the faculties concerned. Mathematical logic is seen as a natural bridge between the disciplines in the school of mathematies and philosophy. The first public examinations (honour moderations) will consist of five papers, of which three will be identical with those of mathematical moderations, one will be on logic, and the last on the theory of knowledge. The final examination will consist of eight papers, four in mathematies, and one, on the history of knowledge, will be identical with one in the PPE school.

Those reading for the school of physics and philosophy will spend two-thirds of the first year on physics to prepare themselves for the advanced work of the last two years. The syllabus will concern itself largely with those branches of physics with most philosophical implications; atomic physies, rather than the solid state or statistical mechanics. There is no doubt that this kind of school in which related subjects are taught concurrently is of great value both to the student and to the community. The pity is that when the courses are held concurrently (rather than consecutively) it is difficult, for administrative reasons, to provide more than a few of the joint schools that might justifiably be started-mathematics or physics with music, psychology with sociology, or biology with mathematics.

\section{Nuffield in Africa}

REvision of school curricula in East Africa seems to have begun well. At a conference organized in March by Credo (Centre for Curriculum Renewal and Educa. tional Development Overseas), representatives of the ministries of education in Kenya, Uganda and Tanzania agreed to collaborate with teachers in a programme of integration and revision of school science in East Africa. Credo, an independent organization financed jointly by the Ministry of Overseas Development and the Nuffield Foundation, believes that the Nuffield science courses, suitably adapted, will provide the much needed modern approach for African schoolchildren. The idea is that teachers in the three East African countries who experiment with these courses can feed their modifications back to a central body which will then incorporate them into the syllabuses. At present, examinations are set by the Cambridge Syndicate, but an East African Examinations Council was set up in February this year. The first examinations from this new body will be set for 1969, in local subjects such as languages and agriculture, with the Cambridge Syndicate moderating the papers to ensure that standards are maintained. Although the syndicate has indicated that it is prepared to consider examinations set on the Nuffield syllabuses, these will have to be set and marked by the East African Council. There is also some scepticism at the syndicate over the question of standards, because it is thought that the Nuffield courses will be more time consuming than the existing ones-evidently African children work more slowly than their English equivalents.

\section{Parliament in Britain}

$$
\text { by our Parliamentary Correspondent }
$$

\section{Construction Industry}

Mr Robert Meulrsh, Minister of Public Building and Works, gave details of the progress of the Construction Industry Research and Information Association. It now had 610 member organizations, he said, but this was only a fraction of what could be achieved. He was trying to arrange a link between the association and the construction industry training board. The association was in the process of appointing staff for a regional advisory service, and he wanted the ministry to be represented on this regional service. (Oral answer, April 29.)

\section{British Standard Time}

Mr William Ross, Secretary of State for Scotland, confirmed that there had been a number of Scottish objections to the decision for Britain to come into line with European time. Seventy-two organizations (county councils, town councils, church and other bodies) had sent him objections, as had twenty-seven private firms and individuals. Two members of parliament had sent petitions signed by their constituents. (Written answer, April 29.)

\section{Technology}

MR WEDGWOOD BENN, Minister of Technology, refused to accept a suggestion from Mrs Winifred Ewing that he should set up an advanced institute of technology in the Northern Highlands of Scotland. He doubted whether it would be feasible. Research within industry might well bring greater and speedier benefits, in any case. (Written answer, April 30.)

\section{Combat Aircraft}

Mr Denis Healey, Minister of Defence, expressed unexpected optimism about the prospects of building an advanced combat aircraft to fill the gap left by the cancellation of TSR 2, F 111 and the Anglo-French variable geometry aircraft. A great deal was going on in the aircraft industry, helped by the money the Government was giving to the BAC design team at Wharton (which is working on a design study for a variable geometry aircraft). Consultations within the department and with European allies were well advanced. "The outcome looks favourable," he added.

\section{Nuclear Power}

The Prime Minister, Mr Harold Wilson, revealed that the House of Commons is likely to be given the chance to debate the report of the Select Committee on Science and Technology on the British nuclear reactor programme. But he did not accept the suggestion (from Mr Woodrow Wyatt) that the money spent on nuclear power stations would have been better spent on coal-fired stations. Dr Ernest Davies said that arguments about power costs would be irrelevant until the various conflicting parties could agree on a basis for these calculations. Otherwise, he said, one was just providing further figures for various lobbyists to quote back and forth to one another. The Prime Minister appeared to agree. Earlier in the week, Mr Wedgwood Benn had confirmed that the chairman of the Industrial Reorganization Corporation was beginning discussions with industry intended to devise a new structure for the nuclear power industry. He would make a statement as soon as a practical solution to this very complex problem became apparent. (Oral answer, May 2, and written answer, April 29.) 